\title{
Perbaikan Kelarutan Albendazol Melalui Pembentukan Kristal Multikomponen dengan Asam Malat
}

\section{(Improvement of Albendazole Solubility Through Multicomponent Crystal Formation with Malic Acid)}

\author{
Fikri Alatas ${ }^{1}$, Fahmi Abdul Azizsidiq ${ }^{1}$, Titta Hartyana Sutarna ${ }^{1}$, Hestyari Ratih ${ }^{1}$, Sundani \\ Nurono Soewandhi ${ }^{2}$ \\ ${ }^{1}$ Fakultas Farmasi, Universitas Jenderal Achmad Yani, Cimahi, Indonesia. \\ ${ }^{2}$ Sekolah Farmasi Institut Teknologi Bandung, Bandung, Indonesia. \\ E-mail:fikri.alatas@lecture.unjani.ac.id
}

Article Info:

Received: 25 Januari 2020

in revised form: 18 Februari 2020

Accepted: 01 Maret 2020

Available Online: 07 Maret 2020

Keywords:

Albendazole

DL-Malic acid

Solvent-drop grinding

Phase solubility

Corresponding Author:

Fikri Alatas

Fakultas Farmasi

Univesitas Jenderal Achmad Yani

Cimahi

40521

Indonesia

email:

fikri.alatas@lecture.unjani.ac.id

\begin{abstract}
An effort to improve the solubility of albendazole (ABZ), an anthelmintic drug has been successfully carried out through the formation of multicomponent crystal with dl-malic acid (MAL). Construction of phase solubility curve of ABZ in MAL solution and crystal morphological observations after recrystallization in the acetone-ethanol (9:1) mixture were performed for initial prediction of multicomponent crystal formation. ABZMAL multicomponent crystal was prepared by wet grinding or also known as solvent-drop grinding (SDG) with acetone-ethanol (9:1) mixture as a solvent followed by characterization of the multicomponent crystal formation by powder X-ray diffraction and Fourier transform infrared (FTIR) methods. The solubility of ABZ-MAL multicomponent crystal was tested in water at ambient temperature and in $\mathrm{pH} 1.2,4.5$ and 6.8 of buffered solutions at $37^{\circ} \mathrm{C}$. The phase solubility curve of the $\mathrm{ABZ}$ in the MAL solution showed type Bs. The ABZ-MAL mixture has a different crystalline morphology than pure ABZ and MAL after recrystallization in the acetoneethanol mixture $(9: 1)$. The powder X-ray diffraction pattern and the FTIR spectrum of ABZ-MAL from SDG different from intact ABZ and MAL powder X-ray diffraction patterns and these results can indicate the ABZMAL multicomponent crystal formation. The ABZ-MAL multicomponent crystal has better solubility than pure ABZ in all media used. These results can be concluded that ABZ-MAL multicomponent crystal can be prepared by solvent-drop grinding method with acetone-ethanol (9:1) mixture as a solvent and can increase the solubility of albendazole.
\end{abstract}

Copyright $(2) 2019$ JFG-UNTAD

This open access article is distributed under a Creative Commons Attribution (CC-BY-NC-SA) 4.0 International license.

How to cite (APA $6^{\text {th }}$ Style):

Alatas, F., Azizsidiq, F. A., Sutarna, T. H., Ratih, H., \& Soewandhi, S. N. (2020). Perbaikan Kelarutan Albendazol Melalui Pembentukan Kristal Multikomponen dengan Asam Malat. Jurnal Farmasi Galenika: Galenika Journal of Pharmacy, 6(1).114-123. doi: $10.22487 / \mathrm{j} 24428744.2020 . v 6.11 .14998$ 


\section{ABSTRAK}

Upaya perbaikan kelarutan albendazol (ABZ), suatu obat anthelmintik, telah berhasil dilakukan melalui pembentukan kristal multikomponen dengan DL-asam malat (MAL). Pembuatan kurva kelarutan fasa ABZ di dalam larutan MAL dan pengamatan morfologi kristal setelah rekristalisasi di dalam pelarut campuran asetonetanol (9:1) dilakukan untuk prediksi awal pembentukan kristal multikomponen. Kristal multikomponen ABZMAL dibuat dengan metode penggilingan basah atau dikenal dengan solvent-drop grinding (SDG) dengan campuran aseton-etanol (9:1) sebagai pelarut, diikuti dengan karakterisasi pembentukan kristal multikomponen dengan metode difraksi sinar-X serbuk dan Fourier transform infrared (FTIR). Kelarutan kristal multikomponen ABZ-MAL diuji di dalam air di suhu ruang dan di larutan dapar $\mathrm{pH} 1,2,4,5$, dan 6,8 di suhu $37^{\circ} \mathrm{C}$. Kurva kelarutan fasa ABZ di dalam larutan MAL menunjukkan tipe Bs. Campuran ABZ-MAL memiliki morfologi kristal berbeda dengan ABZ dan MAL murni setelah direkristalisasi dalam campuran aseton-etanol (9:1). Pola difraksi sinar-X serbuk dan spektrum FTIR hasil SDG ABZ-MAL berbeda dengan pola difraksi sinar-X serbuk ABZ dan MAL murni, dan hasil-hasil ini dapat mengindikasikan terbentuknya kristal multikomponen. Kristal multikomponen ABZ-MAL memiliki kelarutan lebih baik daripada ABZ murni pada seluruh media yang digunakan. Hasil ini dapat disimpulkan bahwa, kristal multikomponen ABZ-MAL dapat dibuat dengan metode solvent-drop grinding dengan campuran aseton-etanol (9:1) sebagai pelarut dan mampu meningkatkan kelarutan albendazol.

Kata kunci: Albendazol; DL-Asam malat; Solvent-drop grinding; Kelarutan fasa.

\section{PENDAHULUAN}

Bentuk sediaan farmasi yang paling banyak dijual (lebih dari $80 \%$ ) adalah tablet, dan sekitar $40 \%$ dari obat yang dipasarkan memiliki sifat kelarutan yang rendah (Babu \& Nangia, 2011; Lohani et al., 2014; Murtaza, 2012). Kelarutan merupakan salah satu sifat fisikokimia penting untuk memprediksi kemampuan absorpsi obat di dalam saluran cerna (Khadka et al., 2014). Kelarutan obat menjadi faktor penentu dari laju disolusinya, dimana laju disolusi yang rendah akibat dari kelarutan rendah obat (kurang dari $100 \mu \mathrm{g} / \mathrm{mL}$ ) seringkali menyebabkan obat-obat yang diberikan secara oral memiliki ketersediaan hayati yang buruk (Kawabata et al., 2011).

Salah satu obat dengan kelarutan rendah dan tersedia di pasaran dalam bentuk sediaan tablet adalah Albendazol (ABZ). ABZ merupakan obat anthelmintik golongan benzimidazol yang bekerja dengan mengikat tubulin dari parasit, menghambat polimerisasi, dan mengganggu pengambilan glukosa (Horton, 2000; Venkatesan, 1998). ABZ termasuk ke dalam kelas II pada biopharmaceutics classification system (BCS) yang memiliki karakteristik kelarutan dalam air rendah dan permeabilitas tinggi (Lindenberg et al., 2004).

Salah satu upaya untuk meningkatkan kelarutan obat tanpa mengubah aktivitas farmakologi adalah dengan memodifikasi bentuk padatan obat melalui pembentukan kristal multikomponen, seperti garam dan ko-kristal (Domingos \& Duarte, 2015; Elder et al., 2013; Thakuria et al., 2013). Kristal multikomponen terbentuk ketika lebih dari satu molekul zat berbeda mengkristal bersama di dalam satu kisi kristal dengan perbandingan stoikiometrik tertentu melalui ikatan nonkovalen. Pembentukan kristal multikomponen, seperti garam dan ko-kristal diketahui mampu meningkatkan kelarutan beberapa obat yang memiliki cincin imidazol di dalam strukturnya, antara lain ketokonazol (Martin et al., 2013), mikonazol (Tsutsumi et al., 2011). Pembentukan garam terjadi akibat adanya transfer proton dari suatu bahan aktif farmasi ke bahan pembentuk garam (salt former) atau sebaliknya, sedangkan pembentukan ko-kristal terjadi akibat adanya ikatan hidrogen antara bahan aktif farmasi dengan bahan pembentuk ko-kristal (co-crystal former).

Asam-asam karboksilat banyak digunakan sebagai bahan pembentuk garam karena mampu mentransfer proton dan membentuk ikatan elektrostatik dengan bahan aktif farmasi yang bersifat basa lemah. Selain itu, asam-asam karboksilat juga digunakan sebagai bahan pembentuk ko-kristal akibat kemampuannya sebagai donor maupun akseptor dalam pembentukan ikatan hidrogen dengan bahan aktif farmasi yang bersifat asam, basa, maupun netral. Salah satu turunan asam karboksilat yang 
banyak diguunakan sebagai bahan pembentuk garam maupun pembentuk ko-kristal adalah asam malat (MAL). MAL diketahui mampu membentuk garam dengan efedrin (Wu et al., 2012) dan baklofen (Córdova-villanueva et al., 2018). Selain dapat membentuk garam, MAL juga diketahui dapat membentuk ko-kristal dengan sulfametoksazol (Imchalee \& Charoenchaitrakool, 2015), kafein (Leyssens et al., 2014), prazikuantel (Cugovčan et al., 2017), dan temozolomid (Babu et al., 2012).

Keberadaan cincin imidazol (Gambar 1a) memberikan peluang bagi ABZ untuk membentuk kristal multikomponen melalui ikatan elektrostatik atau ikatan hidrogen dengan MAL (Gambar 1b). Pada penelitian ini telah dilakukan pembuatan dan karakterisasi pembentukan kristal multikomponen ABZMAL sebagai upaya untuk memperbaiki kelarutan albendazol.

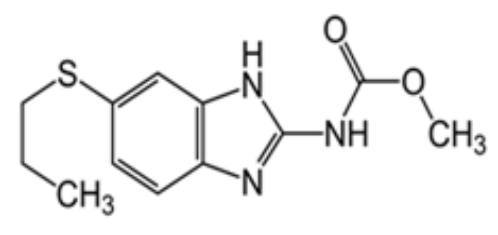

a<smiles>O=C(O)CC(O)C(=O)O</smiles>

b

Gambar 1. Struktur kimia albendazol (a) dan dl-asam malat

\section{METODE PENELITIAN}

\section{Alat dan Bahan}

Alat-alat utama yang digunakan pada penelitian ini adalah difraktometer sinar-X serbuk (Panalytical Empyrean), Shimadzu Affinity-1 FTIR spectrophotometer, spektrofotometer UV-Visible (Shimadzu UV-1800), mikroskop polarisasi (Olympus BX-53), kamera mikroskop (Optilab Advance Plus), dan orbital shaker (IKA KS-260). Albendazol dibeli dari Hubei Zhongjia-chem pharmaceutical co. Itd dengan no. batch U20160402, sementara dl-asam malat (MAL) diperoleh dari Merck Chemical Indonesia. Aseton, etanol, asam hidroklorida, asam asetat, natrium asetat, natrium hidroksida, dan natrium dihidrogen fosfat diperoleh dari Merck Chemical Indonesia tanpa permunian terlebih dahulu.

\section{Metode}

\section{Uji Kelarutan Fasa}

Masing-masing konsentrasi 0,$1 ; 0,2 ; 0,3 ; 0,4 ; 0,5 ; 0,6$; dan $0,7 \mathrm{M}$ larutan MAL dalam air dipipet sebanyak lima $\mathrm{mL}$, dimasukkan ke dalam vial dan ditambahkan $30 \mathrm{mg}$ ABZ. Vial ditempatkan dalam pengocok orbital (IKA KS-260) dan dikocok dengan kecepatan 250 putaran per menit (ppm) di suhu ruang. Sampel disaring setelah 48 jam pengocokan dan filtratnya dianalisis menggunakan spektrofotometri ultraviolet di panjang gelombang 294,8 nm. Konsentrasi ABZ yang terlarut ditentukan berdasarkan persamaan kurva kalibrasi ABZ dalam air.

\section{Pengamatan Morfologi Kristal dengan Mikroskop Polarisasi}

Sebanyak 2-3 mg masing-masing serbuk ABZ, MAL dan campuran fisik ekimolar ABZ-MAL (1:1) ditempatkan di atas object glass, ditetesi campuran pelarut aseton-etanol (9:1) hingga larut, dan dibiarkan mengalami rekristalisasi. Morfologi (habit) kristal yang terbentuk diamati dibawah mikroskop polarisasi yang dilengkapi dengan kamera.

\section{Pembuatan Kristal Multikomponen dengan Metode Solvent-Drop Grinding (SDG)}

Sebanyak $265 \mathrm{mg}$ (1 mmol) ABZ dan $134 \mathrm{mg}$ (1mmol) MAL dimasukkan digerus di dalam mortar selama lima menit dengan penambahan tiga tetes campuran pelarut aseton-etanol (9:1). Hasil penggilingan dibiarkan hingga mengering dan siap untuk dikarakterisasi dan diuji kelarutan. 


\section{Karakterisasi dengan Metode Difraksi Sinar-X Serbuk}

Penetapan pola difraksi sinar-X serbuk dilakukan terhadap ABZ murni, MAL murni dan hasil SDG dari ABZ-MAL (1:1) menggunakan instrument Panalytical Empyrean. Kondisi pengujian menggunakan anode $\mathrm{Cu}$ dengan voltase $40 \mathrm{kV}$ dan arus generator $30 \mathrm{~mA}$ pada rentang sudut $2 \theta=5-45^{\circ}$ dengan kecepatan pindai $2 \%$ menit.

\section{Karakterisasi dengan Metode Fourier Transform Infrared (FTIR)}

Analisis spektrum FTIR dilakukan pada sampel ABZ murni, MAL murni, dan hasil SDG ABZ-MAL (1:1). Masing-masing sekitar lima mg sampel dicampur dengan $25 \mathrm{mg}$ serbuk kalium bromida hingga homogen dan diamati spektrum inframerahnya dengan Shimadzu IRAffinity-1 FTIR Spectrophotometer pada bilangan gelombang 4000 hingga $500 \mathrm{~cm}^{-1}$.

\section{Uji Kelarutan}

Uji kelarutan dilakukan terhadap hasil SDG ABZ-MAL (1:1) dan dibandingkan dengan ABZ murni di dalam pelarut air pada suhu ruang. Uji kelarutan juga dilakukan di dalam larutan dapar asam hidroklorida $\mathrm{pH} \mathrm{1,2,} \mathrm{larutan} \mathrm{dapar} \mathrm{asam} \mathrm{asetat} \mathrm{pH} 4,5$, dan larutan dapar fosfat $\mathrm{pH} 6,8$ pada suhu $37^{\circ} \mathrm{C}$. Masing-masing sampel ditimbang setara $30 \mathrm{mg} \mathrm{ABZ}$, dimasukkan ke dalam vial, dan ditambahkan $10 \mathrm{~mL}$ pelarut. Vial yang berisi sampel dikocok menggunakan orbital shaker (suhu ruang) atau waterbath shaker (suhu $37^{\circ} \mathrm{C}$ ) selama 48 jam. Setelah pengocokan selesai, dilakukan penyaringan sampel yang diikuti dengan analisis filtrat secara spektrofotometri ultraviolet. Kelarutan albendazol dihitung berdasarkan persamaan kurva kalibrasi di masing-masing pelarut.

\section{HASIL DAN PEMBAHASAN}

\section{Kelarutan Fasa}

Kurva kelarutan fasa merupakan suatu kurva yang menunjukkan besarnya konsentrasi suatu solut di dalam berbagai variasi konsentrasi larutan zat lain yang terdiri dari tipe $A_{L}, A_{P}, A_{N}, B_{S}$, dan $B_{L}$ (Higuchi \& Connors, 1965). Tipe kurva kelarutan fasa suatu bahan aktif farmasi di dalam larutan bahan pembentuk garam atau ko-kristal dapat digunakan untuk memprediksi terbentuk atau tidaknya kristal multikomponen. Kurva kelarutan fasa ABZ di dalam variasi konsentrasi larutan MAL dalam air (0,1-0,7 M) yang ditampilkan pada Gambar 2 menunjukkan tipe $\mathrm{B}_{\mathrm{S}}$. Pada rentang konsentrasi larutan asam malat 0,1 hingga $0,5 \mathrm{M}$ terjadi peningkatan kelarutan $\mathrm{ABZ}$ sangat tajam akibat terbentuknya padatan baru berupa kristal multikomponen yang terlarut pada rentang tersebut. Kelarutan ABZ pada rentang konsentrasi larutan MAL 0,5-0,6 M tidak berubah signifikan disebabkan tercapainya keadaan tepat jenuh atau solubility product constant (Ksp) dari kristal multikomponen. Pada rentang konsentrasi MAL 0,6-0,7 M, kelarutan ABZ menurun akibat kristal multikomponen mulai mengendap. Kurva kelarutan fasa ABZ di dalam variasi larutan MAL ini dapat mengindikasikan adanya pembentukan kristal multikomponen akibat interaksi non-kovalen. Kristal multikomponen yang mungkin terbentuk bisa disebabkan oleh yang pertama adanya pembentukan garam, dimana terjadi transfer proton dari MAL ke ABZ atau yang kedua adanya pembentukan ko-kristal, dimana terjadi ikatan hidrogen antara ABZ dan MAL.

\section{Morfologi Kristal}

Hasil pengamatan morfologi kristal di bawah mikroskop polarisasi pada Gambar 3 menunjukkan habit kristal campuran ABZ-MAL setelah direkristalisasi dalam pelarut campuran aseton-etanol (9:1) berbeda dari habit kristal $\mathrm{ABZ}$ dan MAL murni yang direkristalisasi di dalam pelarut yang sama. Habit kristal ABZ berbentuk jarum yang sangat kecil dan habit kristal MAL berbentuk seperti bulir padi besar, sedangkan campuran ABZ-MAL berbentuk batang-batang yang berjajar menyerupai daun. Perbedaan morfologi atau habit kristal ini dapat menjadi salah satu indikasi adanya interaksi antara 
bahan aktif farmasi dengan bahan pembentuk garam/ko-kristal untuk membentuk fasa kristal multikomponen (Liu et al., 2016).

\section{Pembuatan Kristal Multikomponen}

Upaya peningkatan kelarutan albendazol telah dilakukan sebelumnya dengan metode dispersi padat menggunakan eksipien polivinilpirolidon (Kalaiselvan et al., 2006). Namun demikian, peningkatan kelarutan dengan metode dispersi padat memiliki kelemahan akibat terbentuknya padatan amorf yang tidak stabil, sehingga mengalami transformasi kembali ke bentuk kristal saat penyimpanan (Lakshman et al., 2008; Liu et al., 2012). Pembentukan kristal multikomponen berupa garam atau ko-kristal memiliki keuntungan selain dapat meningkatkan kelarutan juga menghasilkan bentuk padatan yang lebih stabil daripada teknik dispersi padat. Salah satu metode sederhana untuk pembuatan kristal multikomponen adalah penggiilingan basah. Metode penggilingan basah atau dikenal dengan solventdrop grinding (SDG) atau liquid-assisted grinding (LAG) adalah salah satu metode pembuatan kristal multikomponen, termasuk garam dan ko-kristal dengan cara menggiling secara bersama-sama bahan aktif farmasi dan bahan pembentuk garam/ko-kristal dengan adanya penambahan sejumlah kecil pelarut (Braga et al., 2013; Hasa \& Jones, 2017; Kaupp, 2009; Trask et al., 2006). Pelarut dapat bertindak sebagai katalis pada pembentukan kristal multikomponen, akibat adanya peningkatan kecepatan pelarutan komponen pembentuknya (bahan aktif farmasi dan bahan pembentuk garam/kokristal), sehingga pemilihan pelarut sangat penting. Pelarut tunggal sering digunakan untuk pembentukan kristal multikomponen, namun pada kasus tertentu yang mana kedua komponen pembentuknya memiliki kelarutan berbeda di dalam pelarut organik, maka pelarut campuran dapat digunakan. Albendazol memiliki kelarutan buruk di dalam air maupun pelarut organik. Namun demikian kelarutan albendazol di dalam aseton sedikit lebih baik daripada di dalam pelarut organik lain. Asam malat praktis tidak larut didalam aseton, namun mudah larut di dalam etanol. sehingga pada pembuatan kristal multikomponen ABZ-MAL dengan metode SDG ini digunakan pelarut campuran aseton-etanol (9:1).

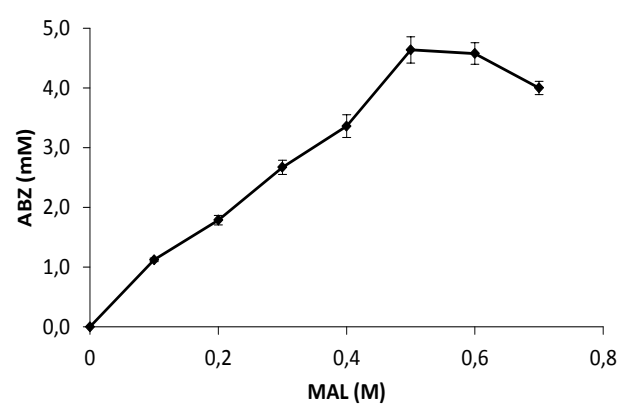

Gambar 2. Kurva kelarutan fasa albendazol (ABZ) di dalam variasi konsentrasi larutan dl-asam malat (MAL) dengan pelarut air. $(n=3)$

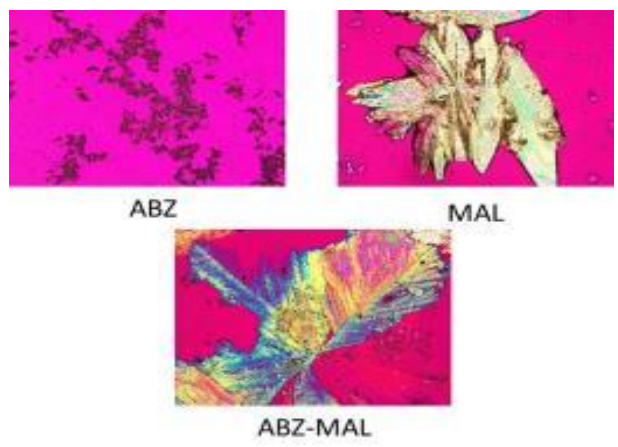

Gambar 3. Fotomikroskop polarisasi kristal multikomponen campuran ABZ-MAL setelah rekristalisasi dalam pelarut campuran aseton-etanol (9:1) dibandingkan dengan ABZ dan MAL murni pada perbesaran 200x. 


\section{Pola Difraksi Sinar-X Serbuk}

Karakterisasi hasil SDG dari ABZ-MAL diawali dengan metode difraksi sinar-X serbuk. Difraktogram sinar-X serbuk dapat memberikan informasi adanya perubahan struktur kristal atau terbentuknya fasa kristal baru dengan menganalisis perbedaan difraktogram antara hasil SDG dengan masing-masing komponen awalnya (Shimpi et al., 2014). Difraktrogram sinar-X serbuk hasil SDG dari ABZ-MAL pada Gambar 4 menunjukkan beberapa puncak ABZ dan MAL murni menghilang dan terbentuknya puncak-puncak baru (panah hitam), dan hasil tersebut mengindikasikan terbentuknya kristal multikomponen ABZ-MAL. Puncak-puncak baru kristal multikomponen terletak pada sudut $2 \theta=12,5,16,1,21,4,23,0,23,9,25,3,26,7,27,5,29,2$, dan $33,1^{\circ}$.

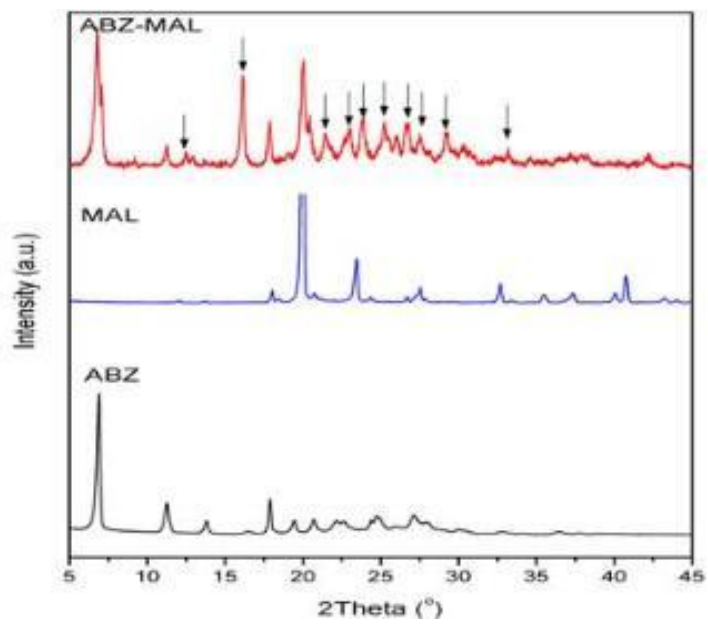

Gambar 4. Pola difraksi sinar-X serbuk kristal multikomponen albendazol-asam malat (ABZ-MAL) dibandingkan komponen-komponen murninya (ABZ dan MAL)

\section{Spektrum Infrared}

Spektroskopi FTIR dilakukan untuk mengkonfirmasi pembentukan kristal multikomponen dengan membandingkan spektrumnya dengan masing-masing komponen pembentuknya (Alatas et al., 2017; Nechipadappu et al, 2017). Hasil pengamatan spectrum FTIR pada Gambar 5 menunjukkan adanya getaran renggang pada $-\mathrm{NH}$ imidazol $\left(3321 \mathrm{~cm}^{-1}\right),-\mathrm{C}=\mathrm{O}\left(1711 \mathrm{~cm}^{-1}\right),-\mathrm{C}=\mathrm{N}\left(1633 \mathrm{~cm}^{-1}\right)$, dan $-\mathrm{C}=\mathrm{C}$ $\left(1589 \mathrm{~cm}^{-1}\right)$ pada albendazol bergeser berturut-turut ke bilangan gelombang 3319, 1713, 1645, 1591 $\mathrm{cm}^{-1}$ pada hasil SDG ABZ-MAL. Getaran renggang -OH yang terikat pada-CHOH dari MAL pada $3346 \mathrm{~cm}^{-1}$ tidak terdeteksi pada hasil SDG ABZ-MAL, sedangkan getaran renggang karbonilnya pada $1728 \mathrm{~cm}^{-1}$ bergeser ke $1745 \mathrm{~cm}^{-1}$. Hasil ini menunjukkan adanya interaksi berupa ikatan ionik atau hidrogen antara ABZ dan MAL untuk membentuk kristal multikomponen.

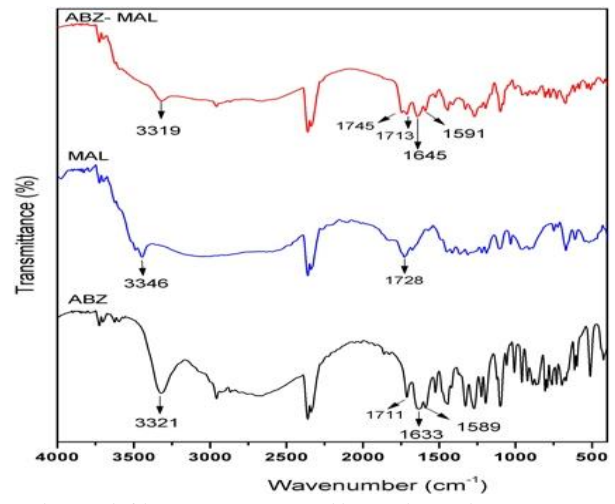

Gambar 5. Spektrum FTIR kristal multikomponen albendazol-asam malat (ABZ-MAL) dibandingkan komponen-komponen murninya (ABZ dan MAL) 


\section{Uji Kelarutan}

Perubahan kristal multikomponen dapat mempengaruhi sifat fisikokimia bahan aktif farmasi, antara lain kelarutan (Berry \& Steed, 2016). Uji kelarutan di dalam air dilakukan pada suhu ruang bertujuan untuk mendapatkan informasi awal yang umumnya diperlukan saat praformulasi sediaan farmasi. Sedangkan uji kelarutan di larutan dapar dengan tiga $\mathrm{pH}$ berbeda dilakukan pada suhu tubuh $\left(37^{\circ} \mathrm{C}\right)$ bertujuan untuk memperoleh informasi kelarutan obat tersebut pada bagian-bagian saluran pencernaan, yaitu $\mathrm{pH}$ 1,2 (lambung dalam keadaan kosong), $\mathrm{pH}$ 4,5 (usus duabelas jari), dan $\mathrm{pH}$ 6,8 (ileum dan jejenum) yang berhubungan dengan proses absorpsi obat ketika diberikan secara oral (Plöger et al., 2018). Tabel 1 menunjukkan kelarutan kristal multikomponen ABZ-MAL lebih baik daripada ABZ murni. Kelarutan ABZ-MAL di dalam air pada suhu ruang 115 kali lipat lebih tinggi daripada ABZ murni, sedangkan di dalam larutan dapar $\mathrm{pH}$ 1,2, 4,5, dan 6,8 berturut-turut 2, 18, dan 14 kali lipat daripada ABZ murni. Peningkatan kelarutan paling rendah ditunjukkan dalam larutan dapar pH 1,2 karena pada suasana asam tersebut ABZ murni mengalami ionisasi dalam pada atom $\mathrm{N}$ imidazole yang menyebabkan kelarutannya menjadi tinggi (Torrado et al., 1996). Sebaliknya peningkatan kelarutan paling tinggi ditunjukkan di dalam pelarut air akibat jumlah ABZ murni yang terionisasi sangat rendah dan adanya ikatan nonkovalen (elektrostatik atau hidrogen) pada kristal multikomponen ABZ-MAL mampu meningkatkan kelarutan albendazol secara bermakna. Peningkatan kelarutan ini dapat disebabkan oleh dua kemungkinan, pertama akibat adanya transfer proton dari MAL ke ABZ (pembentukan garam) yang menyebabkan ionisasi albendazol dan kedua disebabkan oleh berkurangnya energi yang dibutuhkan untuk memutuskan ikatan antara molekul ABZ dan pelarut air akibat adanya ikatan hidrogen (pembentukan ko-kristal) antara ABZ dengan MAL.

Tabel 1. Kelarutan kristal multikomponen ABZ-MAL di dalam berbagai pelarut dibandingkan dengan ABZ murni.

\begin{tabular}{lcc}
\hline Pelarut & \multicolumn{2}{c}{ Kelarutan $(\boldsymbol{\mu g} / \mathbf{m L})$} \\
& ABZ & ABZ-MAL \\
\hline Air $\left(25^{\circ} \mathrm{C}\right)$ & $5,15 \pm 0,03$ & $594 \pm 2,04$ \\
pH 1,2 $\left(37^{\circ} \mathrm{C}\right)$ & $202,67 \pm 1,21$ & $394 \pm 1,13$ \\
pH 4,5 $\left(37^{\circ} \mathrm{C}\right)$ & $4,03 \pm 0,02$ & $72 \pm 0,32$ \\
pH 6,8 $\left(37^{\circ} \mathrm{C}\right)$ & $3,96 \pm 0,02$ & $57 \pm 0,18$ \\
\hline $\mathrm{n}=3$ & &
\end{tabular}

\section{KESIMPULAN}

Upaya perbaikan kelarutan albendazol telah berhasil dilakukan melalui pembentukan kristal multikomponen albendazol (ABZ) dengan dl-asam malat (MAL) yang dibuat dengan metode solventdrop grinding (SDG) menggunakan campuran pelarut aseton-etanol (9:1). Prediksi awal pembentukan kristal multikomponen dengan membuat kurva kelarutan fasa ABZ di dalam variasi larutan MAL dan pengamatan morfologi kristal setelah rekristalisasi di dalam campuran pelarut aseton-etanol (9:1) mengindikasikan terbentuknya kristal multikomponen berupa ko-kristal atau garam ABZ-MAL. Karakterisasi hasil SDG campuran ABZ-MAL dengan menggunakan metode difraksi sinar-X serbuk dan Fourier transform infrared (FTIR) menunjukkan terbentuknya kristal multikomponen ABZ-MAL. Kristal multikomponen ABZ-MAL memiliki kelarutan lebih baik daripada albendazol murni di dalam pelarut air, larutan dapar $\mathrm{pH}$ 1,2, 4,5, dan 6,8. Penelitian ini belum dapat memastikan ikatan yang terjadi antara ABZ dan MAL, sehingga lebih lanjut dapat dilakukan penentuan struktur kristal menggunakan metode difraksi sinar-X kristal tunggal (single-crystal X-ray diffraction) untuk mengetahui bentuk padatan kristal multikomponen sekaligus rasio stoikiometriknya. 


\section{DAFTAR PUSTAKA}

Alatas, F., Aprilliana, M., \& Gozali, D. (2017). The Preparation and Solubility of Loratadine-Fumaric Acid Binary Mixture. Asian Journal of Pharmaceutical and Clinical Research, 10(1), 331-334.

Babu, N. J., \& Nangia, A. (2011). Solubility advantage of amorphous drugs and pharmaceutical cocrystals. Crystal Growth and Design, 11(7), 2662-2679. https://doi.org/https://doi.org/10.1021/cg200492w

Babu, N. J., Sanphui, P., \& Nangia, A. (2012). Crystal engineering of stable temozolomide cocrystals. Chemistry - An Asian Journal, 7(10), 2274-2285. https://doi.org/10.1002/asia.201200205

Berry, D. J., \& Steed, J. W. (2016). Pharmaceutical cocrystals, salts and multicomponent systems; intermolecular interactions and property based design. Advanced Drug Delivery Reviews. https://doi.org/10.1016/j.addr.2017.03.003

Braga, D., Maini, L., \& Grepioni, F. (2013). Mechanochemical preparation of co-crystals. Chemical Society Reviews, 42(18), 7638. https://doi.org/doi.org/10.1039/C3CS60014A

Córdova-villanueva, E. N., Rodríguez-ruiz, C., Sánchez-, O., Rivera-islas, J., Herrera-ruiz, D., Morales-rojas, H., \& Höpfl, H. (2018). Diastereomeric salt formation by the $\gamma$-amino acid $R S$ Baclofen and L-Malic acid: Stabilization by strong heterosynthons based on hydrogen bonds between $\mathrm{RNH}_{3}{ }^{+}$and $\mathrm{COOH} / \mathrm{COO}^{-}$groups. Crystal Growth \& Design, 18(12), 7356-7367. https://doi.org/10.1021/acs.cgd.8b00990

Cugovčan, M., Jablan, J. 2, Lovrić, J., Cinčić, D., Galić, N., Jug, M., \& 1. (2017). Biopharmaceutical characterization of praziquantel cocrystals and cyclodextrin complexes prepared by grinding. Journal OfPharmaceutical and Biomedical Analysis, 15(137), 42-53. https://doi.org/10.1016/j.jpba.2017.01.025

Domingos, S., \& Duarte, M. T. (2015). New forms of old drugs: improving without changing. Journal of Pharmacy and Pharmacology, 67(6), 830-846. https://doi.org/10.1111/jphp.12384

Elder, D. P., Holm, R., \& De Diego, H. L. (2013). Use of pharmaceutical salts and cocrystals to address the issue of poor solubility. International Journal of Pharmaceutics, 453(1), 88-100. https://doi.org/http://dx.doi.org/10.1016/j.ijpharm.2012.11.028

Hasa, D., \& Jones, W. (2017). Screening for new pharmaceutical solid forms using mechanochemistry: A practical guide. Advanced Drug Delivery Reviews, 117, 147-161. https://doi.org/https://doi.org/10.1016/j.addr.2017.05.001

Horton, J. (2000). Albendazole: a review of anthelmintic efficacy and safety in humans. Parasitology, 121, S113-S132. https://doi.org/10.1017/S0031182000007290

Imchalee, R., \& Charoenchaitrakool, M. (2015). Gas anti-solvent processing of a new sulfamethoxazole-1-malic acid cocrystal. Journal of Industrial and Engineering Chemistry, 25, 12-15. https://doi.org/https://doi.org/10.1016/j.jiec.2014.11.009

Kalaiselvan, R., Mohanta, G. P., Manna, P. K., \& Manavalan, R. (2006). Studies on mechanism of enhanced dissolution of albendazole solid dispersions with crystalline carriers. Indian Journal of Pharmaceutical Sciences, 68(5), 599-607. https://doi.org/10.4103/0250-474X.29627

Kaupp, G. (2009). Mechanochemistry: the varied applications of mechanical bond-breaking. CrystEngComm, 11(3), 388. https://doi.org/10.1039/b810822f 
Kawabata, Y., Wada, K., Nakatani, M., Yamada, S., \& Onoue, S. (2011). Formulation design for poorly water-soluble drugs based on biopharmaceutics classification system: Basic approaches and practical applications. International Journal of Pharmaceutics, 420(1), 1-10. https://doi.org/10.1016/j.ijpharm.2011.08.032

Khadka, P., Ro, J., Kim, H., Kim, I., Kim, J. T., Kim, H., ... Lee, J. (2014). Pharmaceutical particle technologies: An approach to improve drug solubility, dissolution and bioavailability. Asian Journal of Pharmaceutical Sciences, 9(6), 304-316. https://doi.org/10.1016/j.ajps.2014.05.005

Lakshman, J. P., Cao, Y., Kowalski, J., \& Serajuddin, A. T. M. (2008). Application of melt extrusion in the development of a physically and chemically stable high-energy amorphous solid dispersion of a poorly water-soluble drug. Molecular Pharmaceutics, 5(6), 994-1002. https://doi.org/10.1021/mp8001073

Leyssens, T., Tumanova, N., Robeyns, K., Candoni, N., \& Veesler, S. (2014). Solution cocrystallization, an effective tool to explore the variety of cocrystal systems: caffeine/dicarboxylic acid cocrystals. CrystEngComm, 16, 9603-9611. https://doi.org/10.1039/C4CE01495B

Lindenberg, M., Kopp, S., \& Dressman, J. B. (2004). Classification of orally administered drugs on the World Health Organization Model list of Essential Medicines according to the biopharmaceutics classification system. European Journal of Pharmaceutics and Biopharmaceutics, 58(2), 265-278. https://doi.org/https://doi.org/10.1016/j.ejpb.2004.03.001

Liu, M., Hong, C., Yao, Y., Shen, H., Ji, G., Li, G., \& Xie, Y. (2016). Development of a pharmaceutical cocrystal with solution crystallization technology: Preparation, characterization, and evaluation of myricetin-proline cocrystals. European Journal of Pharmaceutics and Biopharmaceutics, 107, 151-159. https://doi.org/10.1016/j.ejpb.2016.07.008

Liu, X., Lu, M., Guo, Z., Huang, L., Feng, X., \& Wu, C. (2012). Improving the chemical stability of amorphous solid dispersion with cocrystal technique by hot melt extrusion. Pharmaceutical Research, 29(3), 806-817. https://doi.org/10.1007/s11095-011-0605-4

Lohani, S., Cooper, H., Jin, X., Nissley, B. P., Manser, K., Rakes, L. H., ... Bak, A. (2014). Physicochemical Properties, Form, and Formulation Selection Strategy for a Biopharmaceutical Classification System Class II Preclinical Drug Candidate. Journal of Pharmaceutical Sciences, 103(10), 3007-3021. https://doi.org/10.1002/jps.24088

Martin, F. a., Pop, M. M., Borodi, G., Filip, X., \& Kacso, I. (2013). Ketoconazole salt and co-crystals with enhanced aqueous solubility. Crystal Growth and Design, 13(10), 4295-4304. https://doi.org/10.1021/cg400638g

Murtaza, G. (2012). Solubility enhancement of simvastatin: A review. Acta Poloniae Pharmaceutica Drug Research, 69(4), 581-590.

Nechipadappu, S. K., Tekuri, V., \& Trivedi, D. R. (2017). Pharmaceutical Co-Crystal of Flufenamic Acid: Synthesis and Characterization of Two Novel Drug-Drug Co-Crystal. Journal of Pharmaceutical Sciences, 106(5), 1384-1390. https://doi.org/10.1016/j.xphs.2017.01.033

Plöger, G. F., Hofsäss, M. A., \& Dressman, J. B. (2018). Solubility Determination of Active Pharmaceutical Ingredients Which Have Been Recently Added to the List of Essential Medicines in the Context of the Biopharmaceutics Classification System-Biowaiver. Journal of Pharmaceutical Sciences, 107(6), 1478-1488. https://doi.org/10.1016/j.xphs.2018.01.025 
Shimpi, M. R., Childs, S. L., Boström, D., \& Velaga, S. P. (2014). New cocrystals of ezetimibe with 1proline and imidazole. CrystEngComm, 16(38), 8984-8993. https://doi.org/10.1039/c4ce01127a

Higuchi, T., \& Connors, K. A. (1965). Phase solubility techniques. In Advances in Analytical Chemistry and Instrumentation (pp. 117-212). New York: Jonh Wiley \& Sons, INC.

Thakuria, R., Delori, A., Jones, W., Lipert, M. P., Roy, L., \& Rodríguez-Hornedo, N. (2013). Pharmaceutical cocrystals and poorly soluble drugs. International Journal of Pharmaceutics, 453(1), 101-125. Retrieved from http://dx.doi.org/10.1016/j.ijpharm.2012.10.043

Torrado, S., Torrado, S., Cadorniga, R., \& Torrado, J. J. (1996). Formulation parameters of albendazole solution. International Journal of Pharmaceutics, 140(1), 45-50. https://doi.org/10.1016/0378-5173(96)04545-0

Trask, A. V, Haynes, D. a, Motherwell, W. D. S., \& Jones, W. (2006). Screening for crystalline salts via mechanochemistry. Chemical Communications (Cambridge, England), (1), 51-53. https://doi.org/10.1039/b512626f

Tsutsumi, S., Iida, M., Tada, N., Kojima, T., Ikeda, Y., Moriwaki, T., ... Yamamoto, K. (2011). Characterization and evaluation of miconazole salts and cocrystals for improved physicochemical properties. International Journal of Pharmaceutics, 421(2), 230-236. https://doi.org/10.1016/j.ijpharm.2011.09.034

Venkatesan, P. (1998). Albendazole. Journal of Antimicrobial Chemotherapy, 41(2), 145-147. https://doi.org/10.1093/jac/41.2.145

Wu, H., West, A. R., Vickers, M., Apperley, D. C., \& Jones, A. G. (2012). Synthesis, crystallization and characterization of diastereomeric salts formed by ephedrine and malic acid in water. Chemical Engineering Science, 77, 47-56. https://doi.org/10.1016/j.ces.2011.12.007 